\title{
BIOオECHNOLOGY
}

\section{INDUSTRY MAY BENEFIT FROM EPA REGULATIONS}

$\longrightarrow$ The U.S. Environmental Protection Agency (EPA) has made a bold move in announcing that it intends to regulate the release of genetically modified organisms into the environment see BIO/TECHNOLOGY, 1983, 1:638). Despite the cost (approximately $\$ 10,000$ to file) and the delay (at least 90 days) involved with submitting premanufacturing notices to the EPA, biotechnology product manufacturers will benefit from the regulations. They should welcome the EPA's recent move, a strictly legal interpretation of the influence it already exercises under the Toxic Substances Control Act (TSCA) and the Federal Insecticide, Fungicide, and Rodenticide Act (FIFRA).

The advantages of EPA regulation through TSCA and FIFRA should be apparent when compared with two alternatives: a highly restrictive "guilty until innocent" policy demanding proof of safety, or a policy that ignores environmental consequences. A stricter policy would, in addition to causing unnecessary costs for industry, give the public an impression that products of genetic engineering are unusually dangerous. The alternative "no regulation" policy would encourage carelessness that could lead to harm which would damage the credibility of biotechnology manufacturers. Conversations with EPA officials indicate that the agency will ask for basic information about the product and its manufacture and assess this against evidence indicating potential environmental risk. This policy places the burden upon the EPA as much as it does on the manufacturer.

Part of the good news about the EPA decision is that it will assure the public that products of recombinant DNA technology are not so dangerous that they should be treated differently from other chemical products. The ruling deflates in advance attacks that may be made by some so-called public interest groups that the government is siding with industry against the helpless citizen.

EPA's intention to regulate products offers several additional but hidden advantages to industry. By experimenting and reviewing research literature, the EPA will develop standards for case-by-case assessments, outlining high- and low-risk product areas. This information should help companies assess their R\&D strategies; for example, companies that have avoided areas like pollution control because of lack of environmental impact data or fear of overzealous local regulation should be able to plan on the basis of reliable data and standards.

Finally, EPA's risk assessments, if properly conducted, could help curb unnecessary corporate $R \& D$ costs using genetic engineering. By discovering and publicizing any high-risk products and processes, the EPA saves companies from investing money in products that are risky from the marketing point of view simply because they may pose identifiable harm to the environment.

If the EPA can develop reasonable standards, these benefits will also apply to foreign companies marketing products in the U.S. If EPA's standards work well for industry here, they could also establish a model for European countries to copy. This proved to be the case in regulation of recombinant DNA experimentation in Eu- ropean countries, which were impressed by standards set by the Recombinant DNA Advisory Committee of the National Institutes of Health.

All the benefits of regulation will depend, of course, on EPA doing its job; in light of the agency's embarrassment over the recent toxic waste coverup scandal, the agency would be foolish to be anything but diligent in its future actions. Before companies react too harshly to the extra burden of cost and paperwork that will accompany regulation, they should keep its benefits in mind.

-Christopher G. Edwards

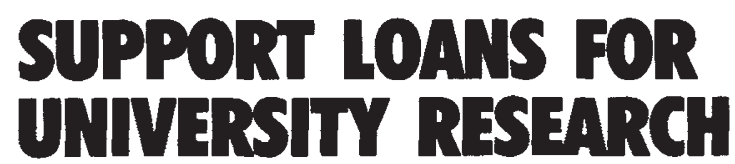

$\mathrm{t}$ is inherently unfair to competing companies, especial1 ly small companies, for an institution to withhold licenses for the most basic tools of any technology. In cases like the Cohen-Boyer process patent and the Axel-Wigler patent granted to Columbia University for cotransformation of eukaryotic cells, nonexclusive licensing to industry is the more equitable method for encouraging widespread industrial development. If patents for the most basic techniques become the sole property of individual companies on the basis of corporate-sponsored university research, the goal of the university-the dissemination of knowledge to benefit society-is compromised.

Nobody can blame universities for seeking up-front money from industry for their basic research. The federal government's grant system cannot keep up with the expansion of interest in or the spiraling cost of research. Although the most prestigious institutions can continue to attract federal money, smaller colleges and universities increasingly find themselves in forced-choice situations. To assure a minimum amount of funding to support basic research, they must consider arrangements with corporations that promise options for exclusive access to results and licensing rights in return for a predetermined amount of financial support.

Universities should evaluate the merits of a new, untested approach to funding research-an approach which assures them of funds without restricting the availability of the resulting technology. They should consider petitioning Congress to enact laws enabling federal agencies to grant special research loans to support basic university research projects with industrial implications. The university could present a set of proposed projects, submitted by department chairmen, to a committee at the National Science Foundation, for example. They would be assessed for their technological implications and scientific merit. If funding was granted for these projects, the universities could assure that the loans would be paid back to the U.S. Treasury through revenues on nonexclusive licensing royalties. The risk of individual projects failing to result in full repayment of loans would be minimized by funding of a variety of projects under the loan program. Even if the Continued on page 806 